\title{
Sensitivity of Annual Weeds against Sulfentrazone 48 SC herbicide in Rice Cultivation
}

\author{
M K A Bhuiyan" ${ }^{1 *}$, M M Mahbub ${ }^{1}$, Z I Baki ${ }^{1}$ and L Nahar ${ }^{1}$
}

\begin{abstract}
Herbicides are used successfully for weed control in rice fields for rapid effect, easier to application and low cost involvement in comparison to the traditional methods of hand weeding. Sulfentrazoneis a new pre-planting herbicide in Bangladesh. Field trials were conducted at Bangladesh Rice Research Institute (BRRI), Gazipur during Aman 2014 and Boro 2014-15 to evaluate the efficacy of Sulfentrazone 48 SC on weed suppression and performance of transplanted rice. Treatments were Sulfentrazone 48 SC @ 150, 200 and $250 \mathrm{ml} \mathrm{ha}^{-1}$, pretilachlor $500 \mathrm{EC} @ 1000 \mathrm{ml} \mathrm{ha}^{-1}$, weed free and unweeded control. Visual assessment indicated that this herbicide possesses high selectivity and not toxic to rice plants. The results revealed that the major weed flora associated with the transplanted rice was mainly comprised of two grasses, two sedges and four broadleaves in Aman 2014 and two grasses, two sedge and two broadleaves in Boro 2014-15. The most dominant weeds were Cyperus difformis, Echinochloa crus-galli, Scirpus maritimus and Monochoria vaginalis in both the growing seasons. Application of Sulfentrazone 48 SC @ $200 \mathrm{ml} \mathrm{ha}^{-1}$ was most effective to suppress weed density and dry masses in both the seasons resulting increased grain yield more than 50\% as compared to unweeded control. Therefore, Sulfentrazone 48 SC @ $200 \mathrm{ml} \mathrm{ha}^{-1}$ should apply two or three days before plantingfor effectively control weeds in rice.
\end{abstract}

Key words: Sulfentrazone, transplanted rice, weed density, weed control efficiency

\section{INTRODUCTION}

Among the cereals, rice (Oryza sativa L.) is the most important and extensively grown in tropical and subtropical regions of the world, and staple food for more than 60 per cent of the world population. The average yield of rice in Bangladesh is $4.5 \mathrm{t} \mathrm{ha}^{-1}$ (BRRI, 2016). Rice production needs to be increased by $50 \%$ or more above the current production level to meet the rising food demand (Sunyob et al., 2015). Weed infestation and interference is a serious problem in rice fields that significantly decreases yield of rice. In Bangladesh weed infestation reduces rice grain yield by $70-80 \%$ in Aus, $30-40 \%$ in transplanted Aman and 22$36 \%$ in modern Boro rice cultivars (BRRI, 2006; Mamun, 1990). Losses due to infestation of weeds are greater than the combined losses caused by insect, pest and diseases in rice (Willocquet et al., 1998 and Bari, 2010). Weeds not only cause huge reductions in rice yields but also increase cost of cultivation, reduce input efficiency, interfere with agricultural operations, impair quality, act as alternate hosts for several insect pests, diseases. They affect aesthetic look of the ecosystem as well as native biodiversity, human and cattle health. Weed competes for nutrient, space, sunlight and consume the available moisture with crop plant resulting in crop yield reduction (Sunyob et al., 2015). Weed infestation in rice cultivation is a major constraint and expensive as well. Since hand weeding including all other weed controlling methods still are not easy so that uses of chemicals are the obvious and cost efficient (Jayadeva, 2010). Now-a-days chemical control of weed has become popular in Bangladesh due to scarcity of labour during peak growing season, and lower cost involvement. In Bangladesh, the annual consumption of herbicides grew over 3,420 metric tons in 2014 (BCPA, 2016) compared to only 108 metric tons during 1986-87 (BBS, 1991), and the growth is almost

\footnotetext{
${ }^{1}$ Agronomy Division, Bangladesh Rice Research Institute, Gazipur, Bangladesh. ${ }^{*}$ Corresponding authors E-mail: bhuiyanbrri@gmail.com
} 
exponential. The traditional methods of weed control practices in Bangladesh are preparatory land tillage, hand weeding by hoe and hand pulling. Mechanical and cultural weed control in transplanted rice is an expensive method. Especially at the peak period of labour crisis sometimes weeding becomes late resulting drastic yield loss. Abundant use of pre and post emergence herbicides such as butachlor, pretilachlor, oxadiazone, pyrazosulfuron ethyl, ethoxysulfuron alone or supplemented with one hand weeding found effective for weed management in transplanted rice (Bhuiyan, 2016). Sulfentrazone has been recently released for pre planting weed control in rice field in Bangladesh. It belongs to Triazolinones chemical group. Mode of action is the destruction of cell membranes by inhibiting the enzyme Protox and consequently the destruction of cell membranes. The chemical formula of sulfentrazone is 4'-dichloro-5'-(4difluoromethyl-4,5-dihydro-3-methyl-5-oxo1H-1,2,4-triazol-1-yl) methane sulfonanilide; $\mathrm{N}$-[2,4-dichloro-5-[4-(difluoromethyl)-4,5dihydro-3-methyl-5-oxo-1H-1,2,4-triazol-1-yl] phenyl] methane sulfonamide. It is a selective herbicide, absorbed mainly by the shoots of germinating plants. It can effectively control most important perennial and annual species of Broadleaf weeds, grasses and sedges in transplanted rice. Furthermore this type of herbicide is almost new adding up in Bangladesh for control of weeds before planting. Therefore, to provide a wider choice of effective herbicide for farmers there is a crucial need to develop environmental friendly molecules of newer chemistries with different mode of action. Considering the situation, the present study was undertaken to evaluate the efficacy of sulfentrazone for annual weed suppression and to find out an appropriate dose and its impacts on transplanted rice.

\section{MATERIALS AND METHODS}

The experiment wasconducted at Bangladesh Rice Research Institute, Gazipur, situated at $23^{\circ} 59^{\prime} 33^{\prime \prime} \mathrm{N}$ and $90^{\circ} 24^{\prime} 19^{\prime \prime} \mathrm{E}$ at an elevation of $8.4 \mathrm{~m}$ from the mean sea level, and is characterized by sub-tropical climate during Aman 2014 and Boro 2014-2015 seasons to evaluate the efficacy of sulfentrazone for weed suppression and to find out an appropriate dose of this herbicide and its impacts on transplanted rice. The commercial name of sulfentrazone is Authority 48 SC. The soil of the experimental field was non-calcareous dark grey flood plain (FAO, 2004) with $\mathrm{pH}$ around 6.2 and low in organic matter $(1.2 \%)$. The experiment was carried out with six treatments. Table 1 presents details of experimental treatments and table 2 presents details of herbicides. All treatments were laid out in a randomized complete block design with three replications. Twenty-fiveday-old seedlings of BRRI dhan 49 for T. Aman 2014 and 35-day-old seedlings of BRRI dhan28 for Boro 2014-2015 were transplanted. Two/ three seedlings per hill were transplanted maintaining $20 \times 20 \mathrm{~cm}$ spacing. The field was fertilized following BRRI recommendation (T. Aman: N:P:K:S= 69:10:41:11 kg ha-1 and Boro; $\mathrm{N}: \mathrm{P}: \mathrm{K}: \mathrm{S}=120: 19: 60: 24 \mathrm{~kg} \mathrm{ha}^{-1}$ ) (BRRI, 2013). Herbicides were sprayed three days before transplanting with the help of a knapsack sprayer. In weed free treatment, the plots were kept weed free up to 45 DAT by hand weeding and check herbicide was Pretilachlor (commercial name is Rifit 500 EC). Authority 48 SC (Sulfentrazone) herbicide is new in Bangladesh and its phytotoxicity needs to be evaluated on rice crop. The phytotoxicity of the herbicide onrice plants was determined by visual observations (yellowing leaves, burring leaf tips, stunting growth etc). The degree of toxicity on rice plant was measured by the following scale used by IRRI (1965):

\begin{tabular}{cl} 
Rating & Symptom \\
\hline 1 & No toxicity \\
2 & Slightly toxicity \\
3 & Moderate toxicity \\
4 & Severe toxicity \\
5 & Toxic (plant killed) \\
\hline
\end{tabular}


Table 1. Weed management treatments of the experimental plots.

\begin{tabular}{llll}
\hline Label & Treatment & $\begin{array}{l}\text { Rate of } \\
\text { application }\end{array}$ & $\begin{array}{l}\text { Application time of herbicide / } \\
\text { Operation of hand weeding }\end{array}$ \\
\hline $\mathrm{T}_{1}$ & Authority 48 SC (Sulfentrazone) $+1 \mathrm{HW}$ on 45 DAT & $150 \mathrm{ml} \mathrm{ha}^{-1}$ & 3 days before transplanting \\
$\mathrm{T}_{2}$ & Authority 48 SC (Sulfentrazone) $+1 \mathrm{HW}$ on 45 DAT & $200 \mathrm{ml} \mathrm{ha}^{-1}$ & 3 days before transplanting \\
$\mathrm{T}_{3}$ & Authority 48 SC (Sulfentrazone ) $+1 \mathrm{HW}$ on 45 DAT & $250 \mathrm{ml} \mathrm{ha}^{-1}$ & 3 days before transplanting \\
$\mathrm{T}_{4}$ & Rifit 500 EC (Pretilachlor) & $1000 \mathrm{ml} \mathrm{ha}^{-1}$ & 3 days after transplanting \\
$\mathrm{T}_{5}$ & Weed free by three hand weeding & - & 15,30 and 45 days after \\
$\mathrm{T}_{6}$ & Unweeded (Control) & - & transplanting \\
\end{tabular}

DAT $=$ Days after transplanting.

Table 2. Details of herbicide.

\begin{tabular}{|c|c|c|c|c|}
\hline Trade name & $\begin{array}{l}\text { Active } \\
\text { ingredients (a. } \\
\text { i.) rate }\end{array}$ & $\begin{array}{l}\text { Name of active } \\
\text { ingredient }\end{array}$ & Chemical name & Chemical family \\
\hline Authority 48 SC & $75 \mathrm{ml}$ ai ha-1 & Sulfentrazone & $\begin{array}{l}\text { 2', 4'-dichloro-5'-(4-difluoromethy 1-4, } \\
\text { 5-dihydro-3-methyl-5-oxo-1H-1, 2, } \\
\text { 4-triazol-1-yl) } \\
\text { methane sulfonanilide; N-[2, 4-dichloro- } \\
\text { 5-[4-(difluoromethyl)-4, 5-dihydro-3- } \\
\text { methy 1-5-oxo-1H- } \\
\text { 1, 2, 4-triazol-1-yl]phenyl] methane } \\
\text { sulfonamide }\end{array}$ & Triazolinones \\
\hline Authority 48 SC & $96 \mathrm{ml}$ ai ha-1 & Sulfentrazone & do & do \\
\hline Authority 48 SC & $120 \mathrm{ml}$ ai ha-1 & Sulfentrazone & do & do \\
\hline Rifit 500 EC & $500 \mathrm{ml}$ ai ha-1 & Pretilachlor & $\begin{array}{l}\text { 2-chloro-2',6'-diethyl-N-(2-propoxyethyl) } \\
\text { acetanilide }\end{array}$ & Chloroacetamide \\
\hline
\end{tabular}

The rating of toxicity was done within 15 days after application of herbicides. It was observed four times- at 6, 9, 12 and 15 days after application and the mean rate was calculated from 10 sample plants of a unit plot.

Data on weed density and dry weight were taken from each plot on $40 \mathrm{DAT}$. The weeds were identified species-wise. Dry weights of weeds were taken by drying them in electric oven at $60^{\circ} \mathrm{C}$ for 72 hours followed by weighing by digital balance. Relative weed density (RWD), relative weed biomass (RWB) and weed control efficiency (WCE) of different weed control treatments were calculated with the following formulas (Tabib et al., 2013 and 2014):

$$
\begin{aligned}
& \operatorname{RWD}(\%)=\frac{\text { Density of individual weed species in the community }}{\text { Total density of all weed species in the community }} \times 100 \\
& \operatorname{RWD}(\%)=\frac{\operatorname{RWD}(\%)+\text { RWB }(\%)}{2} \times 100
\end{aligned}
$$

WCE $(\%)=\frac{\text { Dry weight of weed in weedy check plots-Dry weight of weeds in treated plots }}{\text { Dry weight of weeds in weedy check plots }}$ 
Data on panicle $\mathrm{m}^{-2}$, grains panicle ${ }^{-1}, 1000$ grain weight (TGW), sterility (\%) and grain yield were collected according to the standard protocol. Analysis of Variance of the measured parameters were analyzed and graphical presentation were done by using STAR 2.0.1 software.

\section{RESULTS AND DISCUSSION}

\section{Phytotoxicity of herbicides on rice plant}

Table 3 presents the degree of toxicity of the herbicide to rice plants and the symptoms produced on plant are. It is observed that Authority 48SC@150 $\mathrm{ml} \mathrm{ha}^{-1}$ showed no toxicity and Authority 48 SC @ $200 \mathrm{ml} \mathrm{ha}^{-1}$ showed very slight yellowing of leaves while Authority 48 SC @ $250 \mathrm{ml} \mathrm{ha}^{-1}$ showed moderate yellowing of leaves. Phytotoxicity symptoms observed not more prominent for using this herbicide. Phytotoxicity of rice plant by combined herbicide resulted less which is similar to the findings of Bhuiyan et al., 2010.
Weed infestation during T. Aman season 2014 The rice field was infested with different types of weeds. The relative density of these weed species was also dissimilar (Table 4). Eight different weeds species were observed in unweeded (control) plot where most dominating weeds were sedges and broadleaves. Among the infestation of different categories of weeds, two were grasses, two sedges and four broadleaves. The weed species were belonged to the families of Poaceae, Cyperaceae, Pontederiaceae, Marsileaceae, Sphenocleaceae and Asteraceae. The broadleaf weeds were: Monochoria vaginalis, Marsilea minuta, Sphenoclea zeylanica and Eclipta alba; grasses were: Echinochloa crus-galli, Cynodon dactylon; and sedges were Cyperus difformis and Scirpus maritimus. Among the weed species maximum relative weed density (RWD) was observed for Cyperus difformis (31.24\%) followed by Echinochloa crusgalli $(30.40 \%)$. However, highest relative weed biomass (RWB) was observed for Echinochloa

Table 3. Rating of herbicide toxicity on rice plant under different treatments.

\begin{tabular}{|c|c|c|c|}
\hline \multirow[b]{2}{*}{ Treatment } & \multicolumn{2}{|c|}{ Rating } & \multirow[b]{2}{*}{ Symptom } \\
\hline & $\begin{array}{c}\text { Boro } \\
2014-15\end{array}$ & T. Aman 2015 & \\
\hline Authority 48 SC @ 150 ml ha-1 $\left(72 \mathrm{ml}\right.$ a.i. ha $\left.{ }^{-1}\right)$ & 1.10 & 1.10 & No toxicity \\
\hline Authority 48 SC @ 200 ml ha-1 (96 ml a.i. ha $\left.{ }^{-1}\right)$ & 1.20 & 1.17 & Sometimes slight yellowing of leaves \\
\hline Authority 48 SC @ 250 ml ha ${ }^{-1}$ (120 ml a.i. ha $\left.{ }^{-1}\right)$ & 2.10 & 2.10 & $\begin{array}{l}\text { Slight yellowing of leaves } \\
\text { which required 5-7 days to recover }\end{array}$ \\
\hline Rifit 500 EC @ 1000 ml ha-1 (500 ml a.i. ha $\left.{ }^{-1}\right)$ & 1.10 & 1.15 & No toxicity \\
\hline
\end{tabular}

Table 4. Weed composition, relative weed density (RWD) and relative weed biomass (RWB) in the untreated control plots in Aman 2014 at BRRI, Gazipur.

\begin{tabular}{lcccc}
\hline Weed species & Family & Class & RWD (\%) & RWB (\%) \\
\hline Cynodon dactylon & Poaceae & Grass & 7.65 & 9.63 \\
Echinochloa crus-galli & Poaceae & Grass & 30.40 & 32.75 \\
Cyperus difformis & Cyperaceae & Sedge & 31.24 & 32.45 \\
Scirpus maritimus & Cyperaceae & Sedge & 24.76 & 23.92 \\
Monochoria vaginalis & Pontederiaceae & Broadleaf & 22.28 & 27.29 \\
Marsilea minuta & Marsileaceae & Broadleaf & 11.47 & 12.64 \\
Sphenoclea zeylanica & Sphenocleaceae & Broadleaf & 3.81 & 2.58 \\
Eclipta alba & Asteraceae & Broadleaf & 2.84 & 3.45 \\
\hline
\end{tabular}


crus-galli (32.75\%) followed by Cyperus difformis $(32.45 \%)$. Among the weeds, Eclipta alba was minor weed with 2.84\% RWD and 3.45\% RWB. It was observed that broadleaf weeds were less dominating species. Bhuiyan (2016) explained that efficacy and weed infestation of rice plant depends on different types of herbicides used.

\section{Weed infestation during Boro season 2014-15}

The number of infesting weed species was slightly different in Boro season than in T. Aman season. These weed flora were ecologically categorized into two broadleaves, two sedges and two grasses (Table 5). The major weed was Cyperus difformis of which relative weed density (RWD) and relative weed biomass (RWB) was $32.50 \%$ and $34.07 \%$, respectively. The second dominant weed was Echinochloa crus-galli of which RWD was $31.48 \%$ and relative weed biomass (RWB) was 33.76\%. In Boro season broadleaf weeds created less dominance than in T. Aman season. Authority 48 SC effectively control Echinochola and Cyperus sp. which was similar to the findings of Puniya et al., 2007.

\section{Weed ranking}

The summed dominance ratio (SDR) is an important indicatorto showthe ranking of weeds in a community. The most dominant weeds in T. Aman 2014 were Cyperus difformis, Echinochloa crus-galli, Scirpus maritimus and Monochoria vaginalis (Fig. 1). Cyperus difformis, Echinochloa crus-galli, Scirpus maritimus and Monochoria vaginalis were also the most dominant weeds in Boro 2014-15. Mamun et al., 2011 showed that SDR of a weed against same herbicide was almost similar in different seasons.

Table 5. Weed composition, relative weed density (RWD) and relative weed biomass (RWB) in the untreated control plots in Boro 2014-15 at BRRI, Gazipur.

\begin{tabular}{lllll}
\hline Weed species & Family & Class & RWD (\%) & RWB (\%) \\
\hline Cynodon dactylon & Poaceae & Grass & 10.76 & 9.21 \\
Echinochloa crus-galli & Poaceae & Grass & 31.48 & 33.76 \\
Cyperus difformis & Cyperaceae & Sedge & 32.50 & 34.07 \\
Scirpus maritimus & Cyperaceae & Sedge & 28.16 & 27.63 \\
Monochoria vaginalis & Pontederiaceae & Broadleaf & 21.42 & 26.74 \\
Marsilea minuta & Marsileaceae & Broadleaf & 10.90 & 12.65 \\
\hline
\end{tabular}

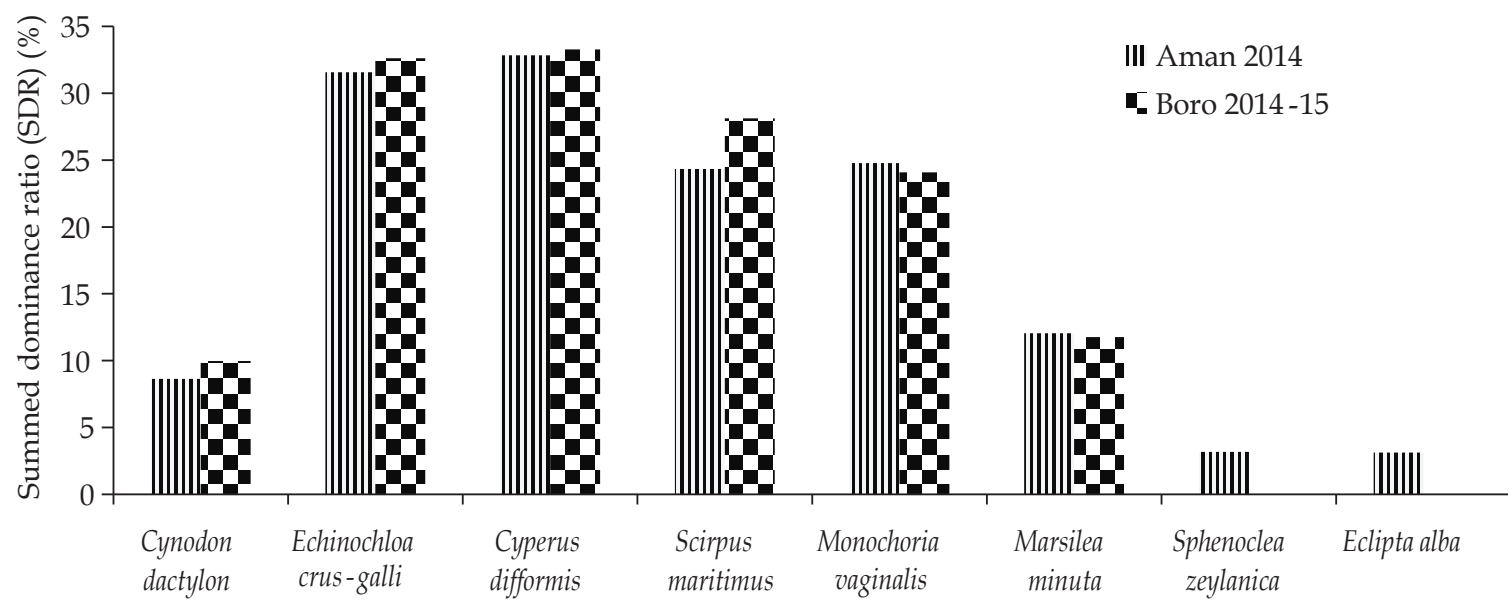

Fig. 1. Summed dominance ratio (SDR) of infesting weeds in transplanted rice. 


\section{Weed control efficiency (WCE)}

Lower weed biomass as well as higher weed control efficiency was observed in all the growing seasons through Authority 48 SC. Weed control efficiency improved with the increases of herbicide dose irrespective of weed species. Treatment $\mathrm{T}_{1}$ did not control all the weeds effectively $(<80 \%)$ due to lower dose of application, whereas $\mathrm{T}_{2}, \mathrm{~T}_{3}$ and $\mathrm{T}_{4}$ control Echinochloa crus-galli, Cyperus difformis, Scripus maritimus and Marsilea minuta more than $80 \%$ in T. Aman season (Table 6). The trend of weed control efficiency in Boro 2014-15 was almost similar to T. Aman 2014 season. All the treatments controlled most of the weeds more than $80 \%$ except $T_{1}$. Treatments $T_{2}, T_{3}$ and $\mathrm{T}_{4}$ controlled Echinochloa crus-galli, Cyperus difformis, Scripus maritimus and Marsilea minuta more than $80 \%$ (Table 7). It was evident from the study that pre planting herbicide Authority
48 SC @ $200 \mathrm{ml} \mathrm{ha}^{-1}$ and $250 \mathrm{ml} \mathrm{ha}{ }^{-1}$ found effective for controlling weeds than other doses of that herbicide. Bhuiyan et al., 2017 reported that different groups of herbicides controlled more than $80 \%$ of weeds in different nitrogen management practices in hybrid rice.

\section{Yield and yield attributes}

Grain yield is the function of an interaction among various yield components, which were affected differentially by the growing conditions and crop management practices. All the treatments significantly increased rice grain yield over unweeded (control) plot (Table 8). In T. Aman 2014, the highest grain yield $\left(5.22 \mathrm{t} \mathrm{ha}^{-1}\right)$ was recorded in $\mathrm{T}_{2}$ treatment which was statistically similar to the treatments of $\mathrm{T}_{4}$ and $\mathrm{T}_{5}$ that produced 4.98 and $5.18 \mathrm{~T} \mathrm{ha}^{-1}$ grain yield respectively. Minimum grain yield

Table 6. Effect of Authority 48 SC on weed control efficiency in transplanted rice in Aman 2014 at BRRI, Gazipur.

\begin{tabular}{lcccc}
\hline \multirow{2}{*}{ Weed } & \multicolumn{4}{c}{ Weed control efficiency (\%) } \\
\cline { 2 - 5 } & $\mathrm{T}_{1}$ & $\mathrm{~T}_{2}$ & $\mathrm{~T}_{3}$ & $\mathrm{~T}_{4}$ \\
\hline Cynodon dactylon & 36.75 & 49.50 & 53.20 & 45.80 \\
Echinochloa crus-galli & 63.45 & 80.95 & 84.50 & 84.61 \\
Cyperus difformis & 70.25 & 82.60 & 83.65 & 81.54 \\
Scripus maritimus & 71.90 & 84.30 & 87.20 & 83.72 \\
Monochoria vaginalis & 65.45 & 74.65 & 78.70 & 80.59 \\
Marsilea minuta & 56.00 & 80.75 & 82.45 & 82.26 \\
Sphenoclea zeylanica & 52.40 & 73.55 & 78.90 & 72.65 \\
Eclipta alba & 54.20 & 63.50 & 66.90 & 62.75 \\
\hline
\end{tabular}

$\mathrm{T}_{1}=$ Authority $48 \mathrm{SC} @ 150 \mathrm{ml} \mathrm{ha}^{-1}, \mathrm{~T}_{2}=$ Authority $48 \mathrm{SC} @ 200 \mathrm{ml} \mathrm{ha}^{-1}, \mathrm{~T}_{3}=$ Authority $48 \mathrm{SC} @ 250 \mathrm{ml} \mathrm{ha}^{-1}$ and $\mathrm{T}_{4}=$ Pretilachlor @ $1000 \mathrm{ml} \mathrm{ha}^{-1}$.

Table 7. Effect of Authority 48 SC on weed control efficiency in transplanted rice in Boro, 2014-15 at BRRI, Gazipur.

\begin{tabular}{lcccc}
\hline \multirow{2}{*}{ Weed } & \multicolumn{4}{c}{ Weed control efficiency (\%) } \\
\cline { 2 - 5 } & $\mathrm{T}_{1}$ & $\mathrm{~T}_{2}$ & $\mathrm{~T}_{3}$ & $\mathrm{~T}_{4}$ \\
\hline Cynodon dactylon & 38.40 & 49.90 & 50.36 & 52.45 \\
Echinochloa crus-galli & 61.35 & 82.60 & 86.90 & 83.35 \\
Cyperus difformis & 72.40 & 82.15 & 85.60 & 85.60 \\
Scripus maritimus & 66.50 & 81.30 & 85.35 & 83.68 \\
Monochoria vaginalis & 60.05 & 75.80 & 78.20 & 83.40 \\
Marsilea minuta & 55.60 & 80.45 & 84.10 & 83.50 \\
\hline
\end{tabular}


Table 8. Effect of Authority $48 \mathrm{SC}$ on yield attributes of transplanted rice at BRRI, Gazipur.

\begin{tabular}{|c|c|c|c|c|c|c|c|c|c|c|}
\hline \multirow{2}{*}{ Treatment } & \multicolumn{2}{|c|}{ Panicle $\mathrm{m}^{-2}$} & \multicolumn{2}{|c|}{ Grain panicle $^{-1}$} & \multicolumn{2}{|c|}{ Sterility (\%) } & \multicolumn{2}{|c|}{ TGW (g) } & \multicolumn{2}{|c|}{ Grain yield $\left(\mathrm{t} \mathrm{ha}^{-1}\right)$} \\
\hline & $\mathrm{S}_{1}$ & $\mathrm{~S}_{2}$ & $\mathrm{~S}_{1}$ & $\mathrm{~S}_{2}$ & $\mathrm{~S}_{1}$ & $\mathrm{~S}_{2}$ & $\mathrm{~S}_{1}$ & $\mathrm{~S}_{2}$ & $\mathrm{~S}_{1}$ & $\mathrm{~S}_{2}$ \\
\hline $\mathrm{T}_{1}$ & 226 & 261 & 17.70 & 16.87 & 105 & 112 & 21.86 & 25.41 & 4.87 & 5.34 \\
\hline $\mathrm{T}_{2}$ & 235 & 286 & 16.13 & 14.63 & 107 & 116 & 21.87 & 25.44 & 5.22 & 5.67 \\
\hline $\mathrm{T}_{3}$ & 214 & 255 & 18.10 & 17.67 & 96 & 104 & 21.75 & 25.42 & 4.69 & 4.97 \\
\hline $\mathrm{T}_{4}$ & 237 & 283 & 17.27 & 15.27 & 103 & 114 & 21.76 & 25.53 & 4.98 & 5.69 \\
\hline $\mathrm{T}_{5}$ & 236 & 287 & 16.23 & 14.60 & 107 & 117 & 21.93 & 25.27 & 5.18 & 5.75 \\
\hline $\mathrm{T}_{6}$ & 186 & 214 & 19.77 & 19.07 & 78 & 93 & 20.84 & 24.92 & 3.21 & 3.37 \\
\hline CV (\%) & 4.56 & 4.03 & 4.05 & 9.06 & 3.47 & 5.14 & 2.2 & 1.1 & 3.48 & 3.51 \\
\hline LSD & 18.48 & 19.35 & 1.29 & 2.69 & 6.28 & 10.26 & ns & ns & 0.29 & 0.32 \\
\hline
\end{tabular}

$\mathrm{S}_{1}=$ Aman 2014, $\mathrm{S}_{2}=$ Boro 2014-15. $\mathrm{T}_{1}=$ Authority $48 \mathrm{SC} @ 150 \mathrm{ml} \mathrm{ha}^{-1}, \mathrm{~T}_{2}=$ Authority $48 \mathrm{SC} @ 200 \mathrm{ml} \mathrm{ha}{ }^{-1}, \mathrm{~T}_{3}=$ Authority $48 \mathrm{SC}$ @ $250 \mathrm{ml} \mathrm{ha}^{-1}$ and $\mathrm{T}_{4}=$ Rifit $500 \mathrm{EC} @ 1000 \mathrm{ml} \mathrm{ha}^{-1}, \mathrm{~T}_{5}=$ Weed free and $\mathrm{T}_{6}=$ control (unweeded).

$\left(3.21 \mathrm{t} \mathrm{ha}^{-1}\right)$ was found in weedy check plots as compared to weed free treatment due to high weed density, which resulted less number of panicle $\mathrm{m}^{-2}$, grains panicle ${ }^{-1}$ and high sterility. Thousand grain weight (TGW) did not differ significantly among the treatments although unweeded plots produced lower TGW in both the years. Treatment wise boxplot of yield attributes in T. Aman 2014 confirmed that most of the yield contributing characters were similar to $\mathrm{T}_{2}, \mathrm{~T}_{4}$ and $\mathrm{T}_{5}$ (weed free) treatments; whereas $T_{6}$ was outsider of the normal range and its data was also in disperse condition than the other treatments due to severe weed infestation (Fig. 2).

Similar trend of results was observed during the Boro 2014-15 where unweeded control $\left(T_{6}\right)$ produced minimum number of panicles $\mathrm{m}^{-2}$, grains panicle ${ }^{-1}$ and high sterility, which resulted lowest grain yield $\left(3.37 \mathrm{t} \mathrm{ha}^{-1}\right)$. The minimum number of panicles $\mathrm{m}^{-2}$ in the control plot was probably due to the higher competition for nutrient, air space, light and water between crop plants and weeds which confirm the results of Hasanuzzaman et al., 2009. Maximum grain yield of $5.75 \mathrm{t} \mathrm{ha}^{-1}$ was recorded with $\mathrm{T}_{5}$ treatment due to lower weedcrop competition. In Boro 2014-15; $\mathrm{T}_{2}, \mathrm{~T}_{4}$ and $\mathrm{T}_{5}$ (weed free) treatments are in similar range in boxplot of yield attributes (Fig. 3). Authority 48 SC@ 150, 200, $250 \mathrm{ml} \mathrm{ha}^{-1}$ gave effective control of grass, sedge and broadleaf weeds lead to increased grain yield. Herbicide treatments contributed to higher yield performance compared to control in all the growing seasons (Bari, 2010).

\section{CONCLUSION}

Grain yield and yield attributing parameters and weed dynamics were greatly influenced by different weed management practices. Authority 48 SC @ $250 \mathrm{ml} \mathrm{ha}^{-1}$ performed better weed control efficiency with slightly phytotoxity. Depending on the weeding efficacy, Authority 48 SC @ $200 \mathrm{ml} \mathrm{ha}^{-1}$ applied at three days before transplanting is effective for annual weed control option instead of hand weeding at peak period of labour crisis which can reduce the production cost. 

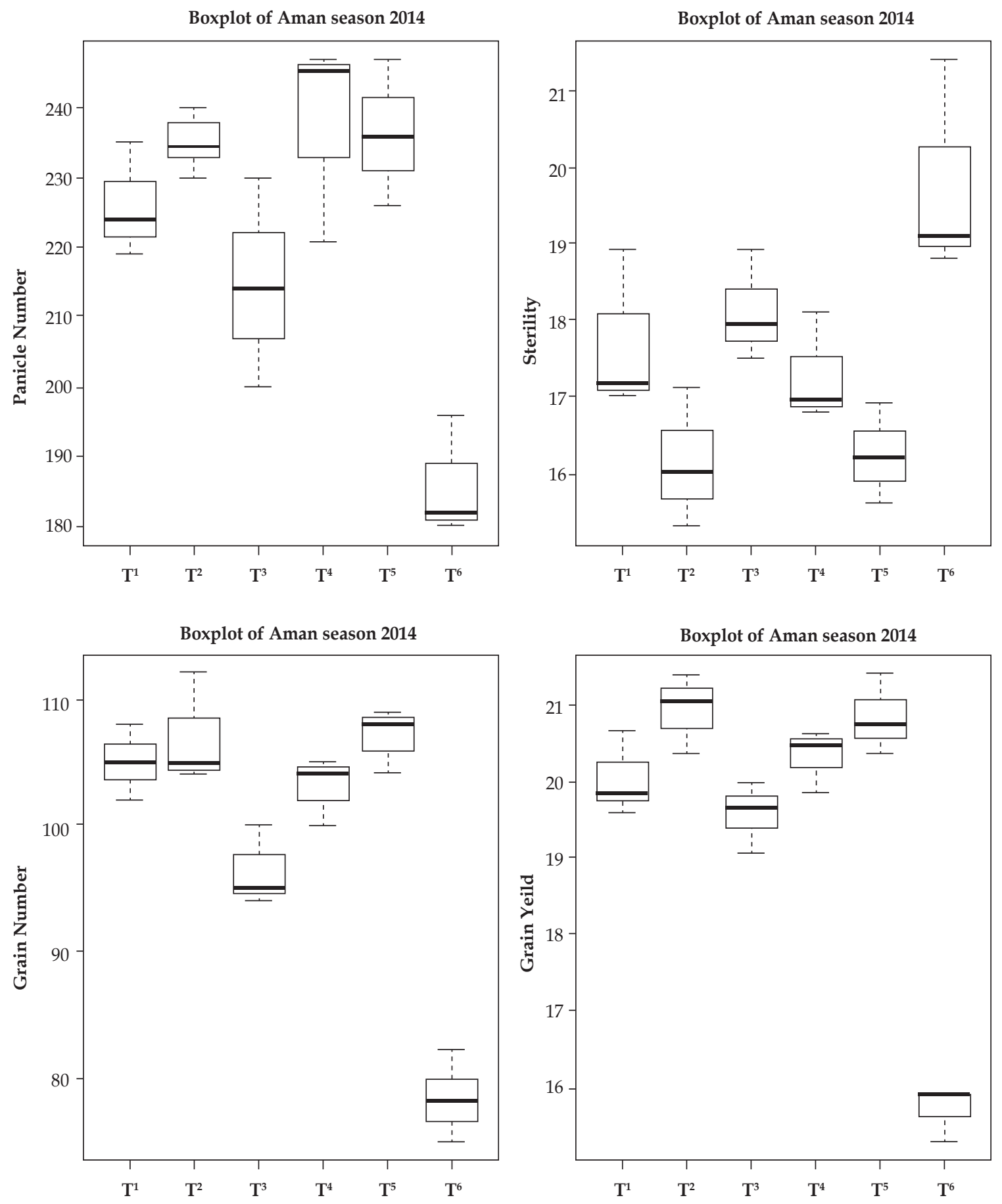

$\mathrm{T}_{1}=$ Authority $48 \mathrm{SC} @ 150 \mathrm{ml} \mathrm{ha}^{-1}, \mathrm{~T}_{2}=$ Authority $48 \mathrm{SC} @ 200 \mathrm{ml} \mathrm{ha}^{-1}, \mathrm{~T}_{3}=$ Authority $48 \mathrm{SC} @ 250 \mathrm{ml} \mathrm{ha}^{-1}$ and $\mathrm{T}_{4}=$ Rifit 500 EC@ $1000 \mathrm{ml} \mathrm{ha}^{-1}, \mathrm{~T}_{5}=$ Weed free and $\mathrm{T}_{6}=$ control (unweeded).

Fig. 2. Boxplot of yield attributes in Aman, 2014 at BRRI, Gazipur. 

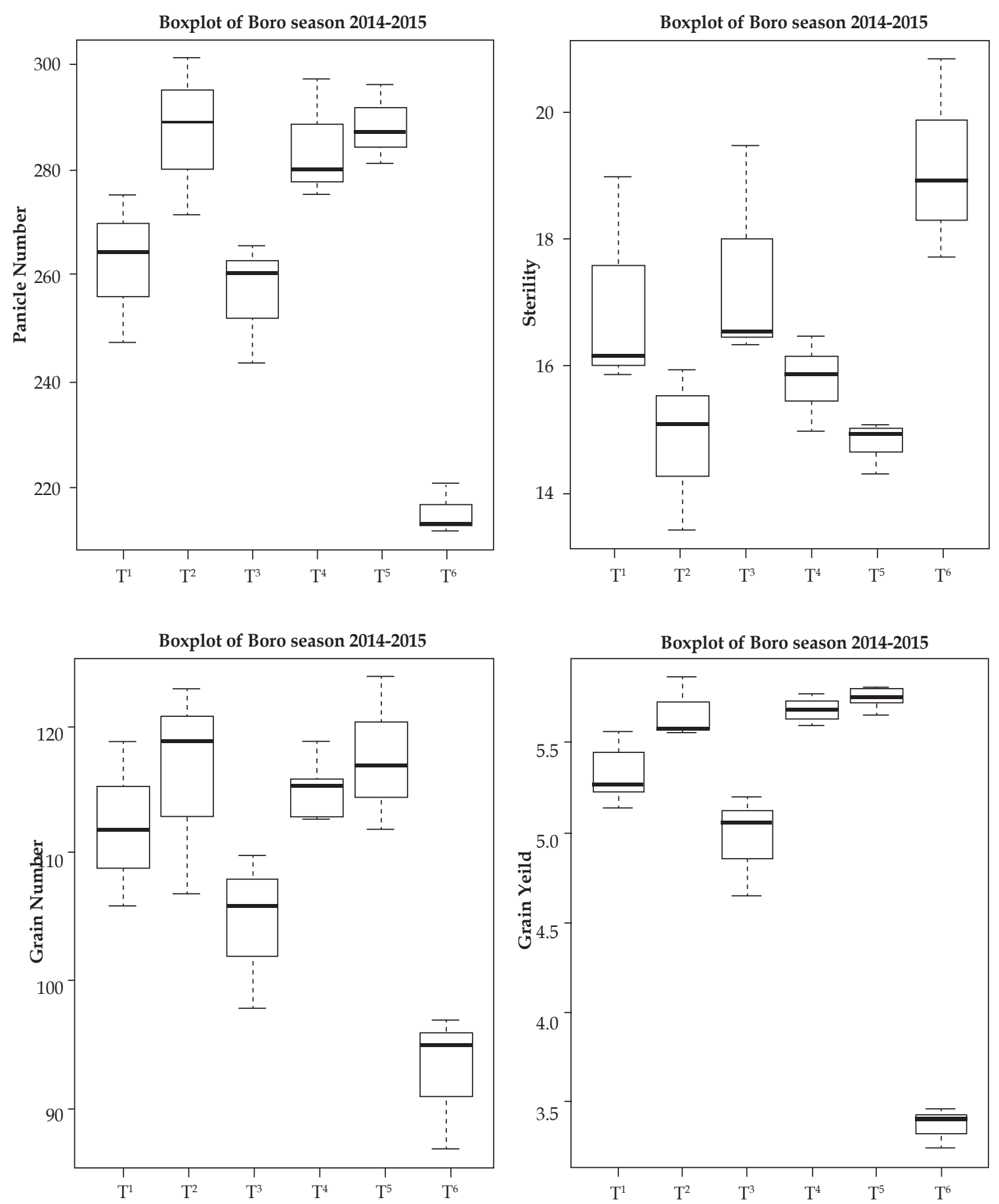

$\mathrm{T}_{1}=$ Authority 48 SC @ $150 \mathrm{ml} \mathrm{ha}^{-1}, \mathrm{~T}_{2}=$ Authority $48 \mathrm{SC} @ 200 \mathrm{ml} \mathrm{ha}^{-1}, \mathrm{~T}_{3}=$ Authority $48 \mathrm{SC} @ 250 \mathrm{ml} \mathrm{ha}^{-1}$ and $\mathrm{T}_{4}=$ Rifit $500 \mathrm{EC}$ @ $1000 \mathrm{ml} \mathrm{ha}^{-1}, \mathrm{~T}_{5}=$ Weed free and $\mathrm{T}_{6}=$ control (unweeded).

Fig. 3. Boxplot of yield attributes in Boro, 2014-15 at BRRI, Gazipur. 


\section{REFERENCES}

Bari, MN 2010. Effects of hetrbicides on weed suppression and rice yield in transplanted wetland rice. Pak. J. Weed Sci. Res. 16 (4): 349-361.

BBS. 1991. Statistical Year book of 1990. Bangladesh Bureau of Statistics, Ministry of Planning, Dhaka.

BCPA. 2016. Office Records of the Bangladesh Crop Protection Association. Dhaka, Bangladesh.

Bhuiyan, M K A. 2016. Effect of resource conservation technologies and weed management on nitrogen use efficiency, growth and yield of rice. Phd thesis. BAU, Mymensingh.

Bhuiyan, M K A and G J U Ahmad. 2010. Performance of Mefenaset +bensulfuron methyl 53\% WP against weed suppression in transplanted paddy. Pak. J. Weed Sci. Res. 16 (2): 181-187.

Bhuiyan, M K A, Md Mostofa Mahbub, Lutfun Nahar and Md Zakaria Ibne Baki. 2017. Effect of Nitrogen levels and weed management on yield performance of BRRI hybrid dhan3 under AWD irrigation system. Bangladesh Agronomy Journal. Vol 20 (1): 13-24.

BRRI. 2006. Weed identification and management in rice. Pub. No. 167, Joydebpur, Gazipur, Bangladesh.

BRRI. 2013. Adhunik Dhaner Chas. Joydebpur, Gazipur, Bangladesh.

BRRI. 2016. Adhunik Dhaner Chas. Joydebpur, Gazipur, Bangladesh.

FAO. 2004. Production Year Book. Food and Agriculture production Function, Iowa State University press, Ames, Iowa, USA. Pp. 63, 105-229.

Hasanuzzaman, M, M O Islam and M S Bapari. 2009. Efficacy of different herbicides over manual weeding in weed control in transplanted rice. Aust. J. Crop Sci. 2 (1): 18-24.

IRRI. 1965. Annual Report for 1963. IRRI, Los Banos, Philippines, pp.224-231.

Jayadeva, H M. 2010. Bioefficacy of post emergent herbicides in weed management of transplanted rice (Oryza sativa L.). Journal of Crop and Weed. 6 (2): 63-66.

Mamun M A A, Shultana R, Islam S A, Badshah M A, Bhuiyan M K A, Mridha A J. 2011. Bio-efficacy of bensulfuron methyl + pretilachlor $6.6 \%$ GR against weed suppression in transplanted rice. Bangladesh Journal of Weed Science 1, 8-11.

Mamun, A A. 1990. Weeds and their control: A review of weed research in Bangladesh. Agricultural and Rural Development in Bangladesh. Japan Intl. Cooperation Agency, Dhaka, Bangladesh. JSARD. 19: 45-72.

Puniya, R P C Pandey and P S Bisht. 2007. Performance of Trisulfuron, Trisulfuron+Pretilachlor and Bensulfuron-methyl in Transplanted Rice (Oryza sativa L.). Indian J. Weed Sci. 39 (1 \& 2): 120-122.

Sunyob, N B, A S Juraimi, M A Hakim, A Man, A Selamat and M A Alam. 2015. Competitive ability of some selected rice varieties against weed under aerobic condition. Intl. J. Agric. and Biol., 17: 61-70.

Tabib, F A I, M T Akhteruzzaman, K Islam and M Khalekuzzaman. 2013 \& 2014. Efficacy of different herbicides over manul weeding in controlling cotton weed. Bangladesh J. Weed Sci. 4 and 5: 39-44.

Willocquet, L, S Savary, L Fernandez, FElazegui and PTeng. 1998. Simulation of Yield Losses Caused by Rice Diseases, Insects, and Weeds in Tropical Asia. IRRI. Discussion Paper Series No. 34 pp. 18-20. 